\title{
Pengaruh Wadah dan Suhu Penyimpanan yang Berbeda terhadap Kematangan Buah Sawo (Manilkara zapota L.)
}

\section{Effect of Containers and Different Storage Temperatures on Sapodilla (Manilkara zapota L.) Maturity}

\author{
Rafif Zuhair Muhammad*, Erma Prihastanti, Rini Budihastuti \\ Program Studi Biologi, Fakultas Sains dan Matematika, Universitas Diponegoro, Semarang \\ *Email: rafifzm257@gmail.com
}

Diterima 6 Januari 2021 / Disetujui 26 April 2021

\begin{abstract}
ABSTRAK
Buah sawo merupakan salah satu komoditas hortikultura yang mempunyai sifat mudah rusak. Buah sawo memerlukan penanganan pascapanen yang baik untuk mengurangi kerusakan pascapanen. Penelitian ini bertujuan untuk mengamati wadah dan suhu penyimpanan yang dapat meningkatkan masa simpan dan mempertahankan kualitas buah sawo. Penelitian ini menggunakan 24 buah sawo terdiri atas 4 perlakuan dan 6 kali ulangan. Setiap ulangan terdiri atas 3 buah sawo yang ditempatkan dalam 2 wadah. Penelitian ini menggunakan perlakuan yaitu $\mathrm{A} 1$ : Wadah plastik yang disimpan pada suhu $15^{\circ} \mathrm{C}, \mathrm{B} 1$ : Wadah kardus yang disimpan pada suhu $15^{\circ} \mathrm{C}$, A2: Wadah plastik yang disimpan pada suhu $27^{\circ} \mathrm{C}, \mathrm{B} 2$ : Wadah kardus yang disimpan pada suhu $27^{\circ} \mathrm{C}$. Penelitian ini menggunakan Rancangan Acak Lengkap (RAL). Parameter yang diukur dalam penelitian ini adalah warna buah, susut bobot buah, total padatan terlarut buah, dan lama penyimpanan buah. Data yang diperoleh kemudian dianalisis menggunakan Analysis of Variance (ANOVA) pada taraf kepercayaan 95\% dan dilanjut uji Duncan dengan $\alpha=0,005$. Hasil penelitian menunjukkan bahwa wadah dan suhu berpengaruh terhadap lama penyimpanan dan kualitas buah sawo. Kombinasi wadah plastik dan suhu $15^{\circ} \mathrm{C}$ dapat meningkatkan masa simpan paling lama diantara perlakuan lainnya, yaitu hingga 12 hari.
\end{abstract}

Kata kunci : hortikultur, pascapanen, pengemasan, susut buah

\begin{abstract}
Sapodilla fruit is one of the horticultural commodities which have the perishable nature. Sapodilla fruit requires good postharvest handling to reduce postharvest damage. This study aims to observe the container and storage temperature that can increase the shelf life and maintain the quality of sapodilla fruit. This study used 24 sapodilla fruit consisting of 4 treatments and 6 replications. Each replication consists of 3 sapodilla fruit which are placed in 2 containers. This study uses treatments namely A1: Plastic containers stored at $15^{\circ} \mathrm{C}$, B1: Cardboard containers stored at $15^{\circ} \mathrm{C}, \mathrm{A} 2$ : Plastic containers stored at $27^{\circ} \mathrm{C}, \mathrm{B} 2$ : Cardboard containers stored at $27^{\circ} \mathrm{C}$. This study uses a Completely Randomized Design (CRD). The parameters measured in this study is the fruit color, fruit weight loss, total dissolved solids fruit and fruit storage time. The data obtained were then analyzed using Analysis of Variance (ANOVA) at the 95\% confidence level and the Duncan test continued with $\alpha=0.005$. The results showed that the container and temperature affected the storage time and quality of sapodilla fruit. The combination of a plastic container and a temperature of $15 \mathrm{oC}$ can increase the longest shelf life among other treatments, which is up to 12 days.
\end{abstract}

Keywords : fruit shrinkage, horticulture, packaging, postharvest 


\section{PENDAHULUAN}

Sawo dikenal juga dengan nama sapodilla (Rozika dkk, 2013). Sawo merupakan buah yang sangat populer di Asia Tenggara, termasuk Indonesia (Shafii et al., 2017). Wilayah ini adalah produsen dan sekaligus konsumen utama buah ini di dunia (Astawan, 2008). Tanaman sawo memiliki banyak manfaat diantaranya buah sawo masak dimakan segar atau dibuat minuman. Kandungan zat gizi dalam buah sawo, yaitu glukosa, vitamin A, B, dan C, karbohidrat dan serat. Buah sawo memiliki khasiat sebagai obat diare dan disentri. Komponen yang beragam pada tanaman sawo seperti saponin dan terpenoid (Fayek et al., 2012) dapat digunakan untuk pengobatan tradisional dan berperan sebagai antiinflamasi, antioksidan, antimikroba, dan analgesic (Srivastava et al., 2014).

Sawo adalah pohon yang tumbuh dengan lambat, dapat tumbuh hingga mencapai ketinggian 5-20 $\mathrm{m}$ tetapi tingginya dapat mencapai $40 \mathrm{~m}$ di hutan, dengan diameter batang rata-rata $1,5 \mathrm{~m}$. Daun sawo memiliki panjang 5$13 \mathrm{~cm}$ dengan bentuk bundar memanjang, bergerombol di ujung tangkai ataupun ranting. Bunga sawo merupakan bunga tunggal, berbentuk lonceng, dan berwarna putih, berdiameter $0,9 \mathrm{~cm}$ dan muncul dari ketiak-ketiak daun dekat ujung ranting pada fase reproduksi (Kaufman \& Kaufman, 2013).

Sawo merupakan buah klimaterik dan membutuhkan penanganan pascapanen yang tepat untuk mencegah terjadinya kehilangan hasil dan menjaga kualitasnya. Waktu panen yang optimal adalah kunci untuk menjaga kualitas buah saat matang (Yahia \& Gutierez-Orosco, 2011). Buah sawo merupakan salah satu komoditas hortikultura yang mempunyai sifat mudah rusak. Oleh sebab itu, buah sawo memerlukan penanganan pascapanen yang baik untuk mengurangi kerusakan pascapanen. Susut pascapanen buah hingga sampai ke konsumen diperkirakan mencapai 40\%. Penyusutan ini disebabkan oleh penanganan yang masih tradisional (Huda, 2015).

Penanganan pascapanen merupakan serangkaian kegiatan yang meliputi pemanenan, pengolahan, sampai dengan hasil siap dikonsumsi Penanganan pascapanen bertujuan untuk menekan kehilangan hasil, menekan laju respirasi, meningkatkan kualitas, daya simpan, daya guna komoditas pertanian, memperluas kesempatan kerja, dan meningkatkan nilai tambah (Meijo, 2008).

Perlakuan pascapanen dapat berupa: pembersihan, pencucian, pengikatan, sortasi, grading, pengemasan hingga sampai ke pemasaran. Perlu adanya penanganan pada produk hortikultura untuk mengurangi penyusutan produk, salah satunya yaitu dengan pengemasan. Pengemasan dapat membantu untuk mencegah atau mengurangi terjadinya kerusakankerusakan. Kerusakan komoditi dapat terjadi karena pengaruh lingkungan luar dan pengaruh kemasan yang digunakan. Pengemasan dapat mempengaruhi mutu pangan antara lain melalui perubahan fisik dan kimia karena migrasi zat-zat kimia dari bahan kemas serta perubahan aroma (flavor), warna, tekstur yang dipengaruhi oleh perpindahan uap air dan O2 (Hailu et al., 2012).

Pengemasan dapat membuat produk tampak menjadi lebih menarik dan pengemasan merupakan hal penting yang harus diperhatikan karena hal tersebut dapat mempengaruhi daya beli konsumen (Usman, 2012). Pengemasan dengan wadah plastik dan kardus biasa dilakukan oleh para pedagang dan distributor sawo. Contohnya adalah penggunaan kardus sebagai tempat penyimpanan biasa digunakan di pasar dan penyimpanan dengan wadah plastik biasa digunakan di supermarket.

Pengaturan suhu merupakan faktor yang sangat penting untuk memperpanjang umur simpan dan mempertahankan kesegaran buah. Semakin rendah suhu penyimpanan maka laju respirasi dan transpirasi akan semakin lambat, begitu juga sebaliknya semakin tinggi suhu maka laju respirasi dan transpirasi akan semakin cepat. Sedangkan kelembaban (relative humidity) mempengaruhi kehilangan air, peningkatan kerusakan, beberapa insiden kerusakan fisiologi, dan ketidakseragaman buah pada saat masak (ripening). Untuk mendapatkan umur simpan sawo yang baik perlu dilakukan penyimpanan dingin suhu optimum penyimpanan sawo adalah 
$14^{\circ} \mathrm{C} \pm 1^{\circ} \mathrm{C} \quad\left(58^{\circ} \mathrm{F} \pm 2^{\circ} \mathrm{F}\right)$ (Kader 2011). Penelitian ini bertujuan untuk mengamati wadah dan suhu penyimpanan yang manakah yang dapat meningkatkan masa simpan dan mempertahankan kualitas buah sawo.

\section{METODE PENELITIAN}

Penelitian dilaksanakan di Laboratorium BSFT Departemen Biologi Fakultas Sains dan Matematika Universitas Diponegoro Semarang pada bulan Januari - Februari 2018. Bahan yang digunakan adalah buah sawo yang masih mentah yang diperoleh dari Kota Rembang, Jawa Tengah. Alat yang digunakan dalam penelitian ini adalah hand refractometer, lemari pendingin, timbangan digital, dan kamera handphone.

Pengambilan buah sawo yang masih mentah berwarna coklat kehijauan dengan diameter panjang $\pm 6 \mathrm{~cm}$ dan lebar $\pm 3 \mathrm{~cm}$ dengan cara memetik menggunakan galah. Buah sawo yang sudah dipetik diseleksi berdasarkan tingkat kematangan dan berat buah. Buah sawo yang sudah diseleksi kemudian disimpan di wadah kardus dan plastik pada suhu $15^{\circ} \mathrm{C}$ dan $27^{\circ} \mathrm{C}$ masing-masing disimpan hingga buah sawo masih bisa dikonsumsi. Buah sawo yang sudah matang diamati secara visual jika terdapat perubahan warna dan keriput pada kulitnya. Seluruh buah sawo ditimbang dengan menggunakan timbangan digital sebelum disimpan, kemudian ditimbang lagi pada hari terakhir pengamatan, kemudian dihitung dengan menggunakan persamaan berikut:

Susut bobot $=\frac{w_{1}^{1-}-w_{2}}{w_{1}} \times 100 \%$

Keterangan:

W1: bobot sampel pada awal penyimpanan $(\mathrm{g})$

W2: bobot sampel pada akhir penyimpanan (g)

Pengamatan total padatan terlarut dilakukan dengan cara buah sawo dibelah menjadi dua, kemudian buah sawo diperas hingga keluar airnya dan air tersebut diteteskan pada bagian prisma. Tutup refraktometer secara perlahan. Untuk melihat hasilnya arahkan alat ke sumber cahaya supaya skalanya terlihat jelas kemudian amati dari lensa pada bagian ujung refraktometer.
Penelitian dilaksanakan dengan menggunakan Rancangan Acak Lengkap dengan 4 perlakuan yaitu: $\mathrm{A} 1$ : Wadah plastik suhu $15^{\circ} \mathrm{C}$, B1: Wadah kardus suhu $15^{\circ} \mathrm{C}, \mathrm{A} 2$ : Wadah plastik suhu $27^{\circ} \mathrm{C}$, B2. Wadah kardus $27^{\circ} \mathrm{C}$ dan dianalisis dengan Analysis of variance (ANOVA) taraf signifikan $95 \%$ dan jika ada perbedaan nyata antar perlakuan diuji lanjut dengan uji Duncan.

\section{HASIL DAN PEMBAHASAN}

\section{Warna Buah}

Pengamatan perubahan warna buah didasarkan pada proses penginderaan, yaitu indra penghlihatan. Pada hari awal penyimpanan semua kulit sawo berwarna hijau kecoklatan. Buah sawo yang disimpan pada wadah plastik dan kardus di suhu $15^{\circ} \mathrm{C}$ menunjukkan perubahan warna yang signifikan dan terdapat pengeriputan pada kulit buah pada hari ke-12, sedangkan buah sawo yang disimpan pada wadah plastik dan kardus di suhu $27^{\circ} \mathrm{C}$ tidak terdapat perubahan warna dan tidak terdapat pengeriputan pada kulit buah pada hari ke-3 dan 4 . Sawo yang disimpan pada suhu $15^{\circ} \mathrm{C}$ terlihat berkeriput sedangkan sawo yang disimpan pada suhu $27^{\circ} \mathrm{C}$ tidak terlihat berkeriput, hal ini disebabkan adanya proses transpirasi yang tinggi pada suhu rendah. Sawo yang disimpan pada suhu dingin memiliki warna kulit yang lebih gelap dibandingkan dengan yang disimpan di suhu ruang, warna gelap ini disebabkan adanya tannin pada kulit buah. Hasil pengamatan menunjukkan bahwa buah sawo masih mampu mempertahankan warnanya sampai dengan 12 hari masa penyimpanan.

Berkurangnya tingkat kecerahan warna pada buah sawo selama penyimpanan diakibatkan oleh berkurangnya kandungan klorofil pada kulit buah sawo dan munculnya karotenoid (Kusumiyati dkk, 2017). Ramadhan (2011) menyatakan bahwa kandungan klorofil selama pematangan buah menurun perlahan, klorofil tersebut mengalami degradasi. Hilangnya warna hijau pada buah karena terjadi oksidasi atau penjenuhan terhadap ikatan rangkap molekul klorofil selama proses kematangan (Mudyantini dkk, 2017). 


\section{Total Padatan Terlarut}

Total padatan terlarut buah berkaitan erat dengan kandungan gula buah karena kandungan yang paling besar yang terukur dalam nilai TPT adalah zat gula. Kandungan gula buah meningkat seiring dengan menurunnya kandungan asam selama pematangan buah (Huda, 2015). Wadah dan suhu penyimpanan yang berbeda mamiliki pengaruh terhadap kadar total padatan terlarut buah (Gambar 1).

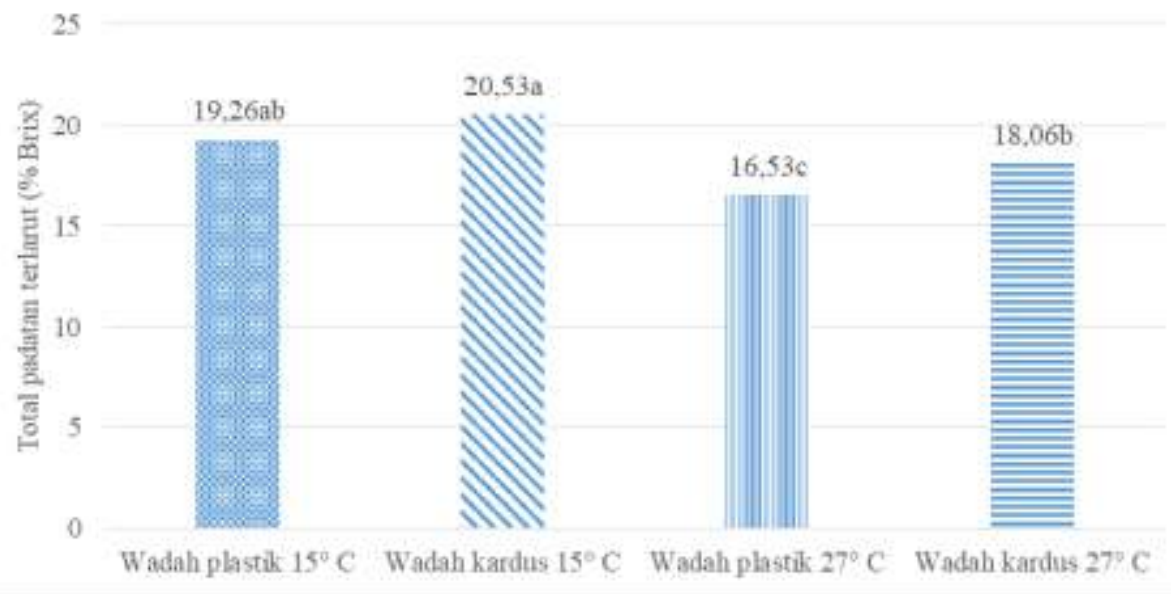

Gambar 1. Kadar total padatan terlarut sawo selama penyimpanan

Selama penyimpanan, total padatan terlarut sawo yang disimpan pada suhu kulkas lebih banyak dibandingkan dengan sawo yang disimpan pada suhu ruang. Hal ini disebabkan karena perlakuan penyimpanan dalam suhu rendah dapat menghambat proses respirasi, sehingga dapat mempertahankan transformasi atau perombakan pati menjadi gula, sedangkan penyimpanan dalam suhu ruang dapat mendukung proses transformasi gula yang lebih cepat, dan apabila buah sawo terlalu lama disimpan gula pada sawo berubah menjadi alkohol sehingga kadar gula menurun.

Menurut Novaliana (2008) kualitas buah ditentukan oleh kandungan kadar gula sebagai total padatan terlarut. Hal ini disebabkan karena buah sawo setelah pasca panen dan masa penyimpanan masih mengalami perubahan fisiologis seperti melunaknya daging buah hingga memasuki masa kelayuan, penurunan gula dan padatan terlarut lainnya.

\section{Susut Bobot}

Kehilangan berat buah-buahan yang disimpan terutama disebabkan oleh kehilangan air. Kehilangan air yang disimpan tidak hanya menurunkan berat, tetapi juga dapat menurunkan mutu dan menimbulkan kerusakan. Proses respirasi dan transpirasi akan menyebabkan komoditi mengalami susut bobot yang dapat disebabkan oleh penguraian glukosa buah menjadi karbondioksida dan kehilangan air. Gas yang dihasilkan akan dapat menguap dan mengakibatkan terjadinya susut bobot (Okvitasari, 2011). Hasil analisis menyatakan perbedaan wadah dan suhu penyimpanan memberikan pengaruh berbeda nyata terhadap susut bobot buah (Gambar 2).

Tingginya susut bobot pada wadah kardus disebabkan wadah kardus yang tertutup rapat sehingga selama penyimpanan buah sawo pada wadah kardus mengalami proses respirasi dan transpirasi paling besar. Kardus memiliki daya serap air yang lebih tinggi dibandingkan dengan plastik. Sifat kertas yang mudah basah pada kondisi lembab dapat menyerap air lebih banyak sehingga susut berat buah sawo semakin meningkat.

Susut bobot selama penyimpanan merupakan salah satu parameter mutu yang mencerminkan tingkat kesegaran buah, semakin 
tinggi susut bobot, maka buah tersebut semakin berkurang tingkat kesegarannya (Rohaeti dkk, 2010). Kehilangan air berpengaruh langsung terhadap kehilangan kualitatif dan menyebabkan kerusakan tekstur, kandungan dan menyebabkan kerusakan lainnya seperti

pengerutan (Sugianti dkk, 2012).

Menurut Sembiring (2009), susut bobot terjadi akibat proses transpirasi, respirasi, dan reaksi-reaksi lain yang ditimbulkan oleh suhu tinggi, suhu rendah, atau kondisi lain yang tidak cocok. Susut bobot terjadi akibat hilangnya air buah dalam proses transpirasi dan menguapnya gas-gas hasil penguraian glukosa menjadi karbondioksida dalam proses respirasi selama penyimpanan.

Transpirasi yang meningkat menyebabkan terjadinya pengeriputan kulit atau pelunakan kulit. Hilangnya ketegaran dinding sel secara bertahap adalah akibat perubahan bentuk protopektin tidak terlarut menjadi pektin terlarut dan bentuk lain. Air dari sel yang menguap menyebabkan sel menjadi mengecil, ruang antar sel menjadi menyatu dan zat pektin yang berada pada ruang antar sel akan saling berkaitan (Silaban dkk, 2013).

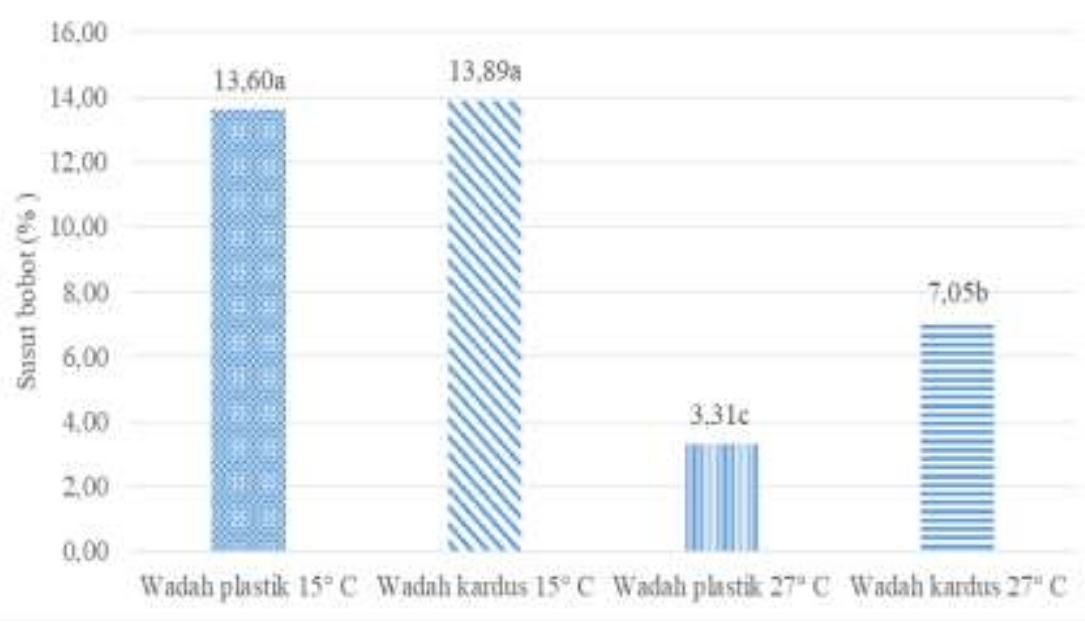

Gambar 2. Susut bobot sawo selama penyimpanan

\section{Lama Penyimpanan}

Untuk mendapatkan umur simpan sawo yang baik perlu dilakukan penyimpanan dingin. Menurut Trisnowati dkk (2012), buah sawo yang disimpan pada suhu rendah terlihat jelas terjadi penundaan pematangan. Kader (2011) mengemukakan bahwa suhu optimum penyimpanan sawo adalah $14^{\circ} \mathrm{C} \pm 1^{\circ} \mathrm{C}\left(58^{\circ} \mathrm{F} \pm\right.$ $2^{\circ} \mathrm{F}$ ) dan berpotensi disimpan selama 2-4 minggu tergantung kultivar dan tingkat ketuaan. Penyimpanan pada suhu dibawah $5^{\circ} \mathrm{C}$ selama lebih dari 10 hari mengakibatkan chilling injury dengan ciri-ciri noda coklat-hitam pada kulit, gagal untuk matang,dan meningkatnya kebusukan jika dipindah ke suhu yang lebih tinggi.

Berdasarkan hasil analisis buah sawo yang disimpan pada suhu $15^{\circ} \mathrm{C}$ memiliki masa simpan yang lebih lama dibandingkan dengan buah sawo yang disimpan pada suhu $27^{\circ} \mathrm{C}$. Hasil uji lanjut DMRT (Duncan's Multiple Range Test) menunjukkan bahwa perbedaan perlakuan berpengaruh terhadap lama penyimpanan sawo (Gambar 3).

Tingkat kemanisan yang tinggi pada suhu rendah disebabkan oleh terhambatnya proses respirasi, sehingga dapat mempertahankan transformasi atau perombakan pati menjadi gula. Hal ini menunjukkan bahwa suhu dingin dapat menekan proses respirasi sehingga proses penyimpanan sawo berlangsung lebih lama. Suhu penyimpanan yang tinggi dapat mempersingkat daya simpan buah karena dapat mempercepat laju respirasi sehingga buah lebih cepat mengalami kelunakan dan penurunan kandungan air. Pelunakan pada buah berhubungan secara langsung dengan kehilangan air dari buah. 
Peningkatan pelunakan disebabkan oleh terjadinya penguapan air. Air dari sel pada jaringan daging buah yang menguap menyebabkan sel menjadi mengecil, ruang antar sel menjadi menyatu dan zat pektin yang berada pada ruang antar sel akan saling berkaitan (Silaban dkk, 2013).

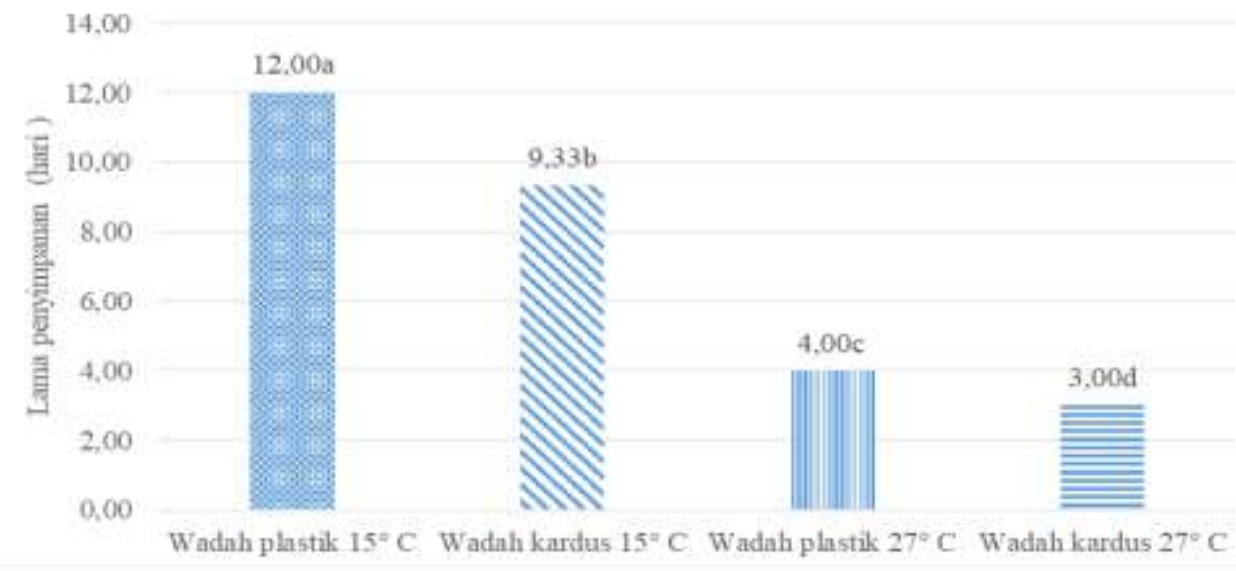

Gambar 3. Lama penyimpanan sawo selama penelitian

\section{KESIMPULAN}

Wadah dan suhu penyimpanan berpengaruh terhadap masa simpan dan kualitas buah sawo. Kombinasi wadah plastik dan suhu $15^{\circ} \mathrm{C}$ mampu memperpanjang masa simpan buah sawo hingga 12 hari dan mempertahankan kualitasnya.

\section{DAFTAR PUSTAKA}

Fayek NM, Monem AR, Mossa MY, Meselhy MR, Shazly AH. 2012. Chemical and biological study of Manilkara zapota (L.) Van Royen leaves (Sapotaceae) cultivated in Egypt. Pharmacogn Res. 4(2):85-91.

Hailu, M., Workneh, TS., Belew, D. 2012. Effect of packaging materials on the quality of banana cultivars. African Journal of Agricultural Research 7 (7): 1226 1237. DOI: 10.5897/AJAR11.2104.

Huda, M.A, Trisnowati S, Putra E.T.S. 2015. Tanggapan Buah Sawo (Manilkara zapota (L.) van Royen) Terhadap Kadar Dan Lama Perendaman Dalam Larutan $\mathrm{CaCl}_{2}$. Fakultas Pertanian Universitas Gadjah Mada Yogyakarta.
Kader A.A. 2011. Sapotes : (Sapodilla \& Mamey Sapote) Recommendations for Maintaining Postharves Quality. University of California. http://postharvest.ucdavis.edu/PFfruits/ Sapotes/?email=yes.

Kaufman, S.R, Kaufman W, 2013. Invasive plants. Guide to identification and the impacts and control of common North American species. Second edition, revised and updated. Mechanicsburg, PA, USA: Stackpole Books, 528 pp.

Kusumiyati, Mubarok S, Sutari W, Hadiwijaya FY, dan Putri IE. 2017. Kualitas Sawo (Achras zapota L.) Kultivar Sukatali Selama Penyimpanan. Program Studi Agroteknologi Fakultas Pertanian Universitas Padjadjaran.

Meijo, D.J. 2008. An Overview of Rice Postharvest Technology: Use Of Small Metallic for Minimizing Losses. Agricultural Industries Officer, Agricultural and Food Engineering Technologies Service, FAO, Rome. FAO Corporate Document Repository.

Mudyantini W, S. Santosa, Kumala Dewi, Nursigit Bintoro. 2017. Pengaruh Pelapisan Kitosan dan Suhu Penyimpanan terhadap Karakter Fisik 
Buah Sawo (Manilkara achras (Mill.) Fosberg) Selama Pematangan. Program Studi Biologi, Fakultas Matematika dan Ilmu Pengetahuan Alam, Universitas Sebelas Maret. Surakarta.

Novaliana, N. 2008. Pengaruh Lapisan dan Suhu Simpan Terhadap Kualitas dan Daya Simpan Buah nenas (Ananas comosus L. Merr). Skripsi. Departemen Agronomi dan Hortikultura. Institut Pertanian Bogor.

Okvitasari, H. 2011. Kajian Gejala Chilling Injury Terhadap Perubahan Mutu Buah Mangga Varietas Gedong Gincu Selama Penyimpanan Dingin. Skripsi. Departemen Teknik Dan Biosistem, Institut Pertanian Bogor. Bogor.

Ramadhan, R.E. 2011. Lama Penyimpanan Dan Mutu Buah Sawo (Manilkara zapota L.)Kultivar Sukatali ST1 Yang Dilapisi Lilin. Skripsi. Departemen Teknik Dan Biosistem. Fakultas Teknik Pertanian. Institut Pertanian Bogor, Bogor.

Rozika, R.H. Murti \& S. Purwanti. 2013. Eksplorasi dan Karakterisasi Sawo (Manilkara zapota (L.) van Royen) di Daerah Istimewa Yogyakarta. Vegetalika 2(4): 101-114.

Sembiring, N.N. 2009. Pengaruh Jenis Bahan Pengemas Terhadap kualitas produk Cabe merah (Capsicum annum L) segar kemasan selama Penyimpanan Dingin. Tesis Sekolah Pasca Sarjana Universitas Sumatera Utara. Medan.

Shafii, Z.A., M. Basri, E.A. Malek, \& M. Ismail. 2017. Phytochemical and Antioxidant Properties of Manilkara zapota (L.) P Royen Fruit Extracts and Its Formulation for Cosmeceutical Application. Asian J. Plant Sci. Res. 7(3):29-41.

Silaban, S.D. Prihastanti E. Saptiningsih E. 2013. Pengaruh Suhu dan Lama Penyimpanan Terhadap Kandungan Total Asam, Kadar Gula serta Kematangan Buah Terung Belanda (Cyphomandra betacea Sent.). Buletin Anatomi dan Fisiologi 21.
Srivastava, A.K, Bade G, Khan, M.A. 2014. Serum cytokine profiling and enrichment analysis reveal the involvement of immunological and inflammatory pathways in stable patients with chronic obstructive pulmonary disease. International Journal of Chronic Obstructive Pulmonary Disease. 9:759-773. doi:10.2147/COPD.S61347.

Trisnowati S., Suyadi, Wahyuni P. S., Adhayati N. 2012. Menunda kerusakan buah sawo (Manilkara zapota (L.) van Royen) dengan berbagai lama penyinaran UV-C dan penyimpanan pada suhu rendah. Ilmu Pertanian 15(2): $100-112$.

Usman, A. 2012. Pengemasan Produk Pasca Panen. Bogor: IPB Press.

Yahia, E.M. Gutierez-Orosco F. 2011. Sapodilla (Manilkara archas (Mill) Fosb., syn Achras zapota L.). Autonomous University of Queretaro, Mexico. 